\title{
В. В. РЯБКОвА
}

\section{Развитие речевой деятельности с помощью мобильных устройств и их приложений (на примере английского языка)}

Предложен комплекс практических заданий, направленных на развитие четырех видов речевой деятельности: чтение, аудирование, письмо и говорение. Цель исследования - выявить наиболее эффективные типы заданий, которые могли бы быть выполнены с помощью мобильных устройств и мобильного интернета. Мобильные устройства широко используются, что можно объяснить их практичностью (они всегда под рукой, и люди могут использовать их в любое время и в любом месте, когда пожелают). Изучены различные типы заданий и представлены те, к которым обучающиеся проявили наибольший интерес. Проанализированы мобильные обучающие платформы, которые были изначально разработаны для образовательных целей и те, которые были созданы для профессиональных задач, но которые могут быть эффективно использованы при изучении иностранного языка. Предложенные задания рассматриваются в качестве дополнительного ресурса для работы обучающихся как очно, так и дистанционно. Экспериментальное обучение было проведено в очной форме обучения по программе дополнительного профессионального образования. Представлены результаты исследования и выводы, которые были сделаны на основе проведенного опроса среди обучающихся. Полученные результаты показали, что мобильные технологии могут помочь обучающимся улучшить и сохранить их уровень владения языком, а также поддержать их мотивацию. Представленные мобильные технологии могут успешно применяться как преподавателями, так и обучающимися.

Ключевые слова: мобильное обучение, мобильные устройства, языковые навыки, «мозговой штурм», коммуникативная компетенция, владение языком, изучаемый язык, взрослые обучающиеся, интернет

\section{Ссылка для цитирования:}

Рябкова В. В. Развитие речевой деятельности с помощью мобильных устройств и их приложений (на примере английского языка) // Перспективы науки и образования. 2019. № 2 (38). С. 320-326. doi: 10.32744/pse.2019.2.24 


\section{V. RYABKOVA}

\section{Mobile devices and apps for developing language skills (on the example of the English language)}

This article presents a set of practical tasks aimed at developing 4 basic language skills: reading, listening, writing and speaking. The purpose of the study is to identify effective tasks that can be performed with the help of mobile devices and mobile Internet. Mobile devices are widely used and it can be explained by their convenience (they are always at hand and people make use of them at any time and in any place they like). We examined different types of mobile tasks and presented some of them that appeared to be the most exciting for learners. We also analyzed different mobile learning platforms that were initially designed for educational purposes and others that were created for professional purposes but can be effectively implemented into the educational process. These mobile activities are regarded as an additional source that should be implemented together with traditional methods for learners' in and outside the classroom educational process. The experimental learning was carried out with full-time learning form within the program of Additional Vocational Education. This article also presents the results of the research and the conclusions that were made on the basis of the conducted survey after the experimental learning. The obtained results show that mobile technologies can help learners improve and maintain the level of their language proficiency and sustain their motivation. Therefore the present mobile technologies can be successfully applied by teachers and learners.

Keywords: mobile learning; mobile devices; language skills; 'brain storm'; communicative competence; language proficiency; target language; adult learners; Internet

\section{For Reference:}

Ryabkova, V. V. (2019). Mobile devices and apps for developing language skills (on the example of the English language). Perspektivy nauki i obrazovania - Perspectives of Science and Education, 38 (2), 320-326. doi: 10.32744/pse.2019.2.24 
V odern era is characterized by impetuous changes in all spheres of human life, it also concerns educational sphere. Highly educated individuals are of great importance for the development of the country. Consequently, new technologies are becoming significant; they boost people's further development. The term "technologies" is regarded differently, for example, such combination of words as "educational technologies" means methods that realize teacher's and learners' work organization. However, "technologies in education" implies using of new technologies in the educational process. Consequently, the two notions should be distinguished.

Today one of the most advanced forms of education is mobile learning or M-learning. Many researchers all round the world are interested in this relatively new educational trend, for example, G. Zurita (2004), Agnes Kukulska-Hulme (2005, 2015), J. Traxler (2005, 2009), David S. Metcalf (2006), A. Avramenko (2013), H. Crompton (2015), Katharine B. Nielson (2016), S. Wilden (2017), S. Titova (2017), A. Umirov (2017), V. Yepez-Reyes (2018) and others. There are also many definitions of M-learning, we will analyze some of them. According to the definition that was proposed by an international group of researchers, "it is the experience and opportunity afforded by the evolution of educational technologies. It is anywhere, anytime learning enabled by instant, ondemand access to a personalized world filled with the tools and resources we prefer for creating our own knowledge..."[7, p. 8]. J. Traxler regards M-learning as "learning that used to be delivered 'just-in-case', can now be delivered 'just-in-time, just enough, and just-for-me'" [12, p. 14]. S. Wilden defines the term as "learning through the use of mobile devices. ...it has the ability to bring real life into the classroom" [14, p. 5]. The definitions are different but all of them are based on the technical component: the idea is that mobile learning can be realized with the help of mobile devices. Mobile device is a portable multimedia tool that performs many of the functions of a stationary computer. Mobile devices can be as follows: smartphones (the most widespread ones), tablets, MP3 players, e-readers, notebooks etc. The integration of mobile learning into the traditional educational process is not a challenge for contemporary learners even adult ones because today everyone has at least one mobile device that is always at hand. And the overwhelming majority of people use their devices many times a day. Some institutions have an opportunity to organize the purchase of mobile devices for educational purposes but in most cases institutions pursue the policy of "Bring Your Own Device" (BYOD) that is cost-effective [14].

\section{Research methods and materials}

Mobile learning requires new forms of tasks because it is not enough to convert traditional assignments into a mobile form. Different tasks are aimed at developing reading, listening, writing and speaking skills as a whole. We have created a number of tasks according to the 4 basic language skills. The examples of some of the tasks are presented in Table 1. 
Table 1

Language skills and corresponding tasks

\begin{tabular}{|c|c|}
\hline Skills & Tasks \\
\hline Reading & $\begin{array}{l}\text { Online blogs (LiveJournal.com; Medium.com; blogger.com etc.) } \\
\text { Task 1: Read the text online. } \\
\text { Task 2: Make up a list of the key words/phrases that could be used while } \\
\text { summing up the content. Use "notes" on your device. } \\
\text { Task 3: Express your opinion on the topic in the text. }\end{array}$ \\
\hline Listening & $\begin{array}{l}\text { Audio player, WhatsApp audio files, e-mail audio files, link to an } \\
\text { audio file etc. } \\
\text { Task 1: Listen to the recording. Use your personal headphones. } \\
\text { - Google Forms [4] } \\
\text { Task 2: Test your understanding. Complete the test multiple choice. } \\
\text { Task 3: Make up } 5 \text { different questions to the text. Use iBrainstormapp.com. } \\
\text { Compare the questions and answer them. }\end{array}$ \\
\hline Writing & $\begin{array}{l}\text { - Notes, e-mail, WhatsApp, blogs. } \\
\text { Task 1: Have a look at the list of the key words. } \\
\text { Make up a plan of your story according to the key words. } \\
\text { Task 2: Write a story using the key words (each word should be used at least } \\
\text { once). } \\
\text { Task 3: Share your story with the colleagues. }\end{array}$ \\
\hline Speaking & $\begin{array}{l}\text { - YouTube. com, audio/video recorder. } \\
\text { Task 1: Watch the video online. } \\
\text { Task 2: Think about the topic stated in the video. } \\
\text { Task 3: Express your opinion on the topic. Use audio/video recorder. Share it } \\
\text { with your colleagues on WhatsApp. } \\
\text { Task 4: Discuss the ideas. Use iBrainstormapp.com or video conferencing. }\end{array}$ \\
\hline
\end{tabular}

The tasks that are aimed at developing reading skills are based on the investigation carried out by the Russian researchers S. Korovina, A. Pushkina and N. Gurova [5]. The research focuses on online blogs in the process of development of reading skills. The results of the research show that "blog environment helps increase and sustain students' motivation for learning English as well as teaches to make use of particular English-language web resources"[5, p. 305]. Moreover, online blogs contributes not only to developing language skills but communicative competence on the whole.

As for listening skills we suggest developing them by using audio player that is a basic application on most mobile devices. Every learner can listen to the recording using personal headphones with the opportunity to adjust the sound to the ear. The advantage of mobile device in this case is that learners can do listening exercises on the move at any time they like. The two foreign researchers T. Read and A. Kukulska-Hulme conducted an experiment, 90 students participated in it [10]. The researchers focused on the possible benefits of using mobile apps for motivating the practice of listening comprehension, as it plays a significant role for foreign language learners. The experiment was based on audio news and showed that most participants were interested in listening to different news, doing tasks before, during and after it takes place and even commenting on the news on the Facebook page. We think that the tasks that we suggested also contribute to the increase of learners' motivation and interest. Moreover we suggest learners comment on the recording and discuss the topic using iBrainstormapp.com (multi-device collaboration tool). Such online platforms help 
teachers to trace the contribution of each learner to the collective discussion. The platform is also very useful for learners as it visualizes the process of thinking and helps to assimilate more information effectively. All 'brain storm' platforms are based on the 'mind map' study technique that was first presented by T. Buzan in 1974 in his book "Use your head" [2].

Listening is an essential part of effective communication and it is considered to be one of the most difficult skills that learners face. Therefore we provide a concrete example. The teacher chooses an audio text to listen to that corresponds to the syllabus and the level of the learners' proficiency, downloads it and prepares particular tasks: test multiple choice and questions. For example, the topic "Telephone: appointments": http://www.bbc.co.uk/ worldservice/learningenglish/business/talkingbusiness/unit1telephone/4appointments. shtml. We suggest the teacher presents the task in class at first. The teacher sends the link to the audio file to learners and before they listen to the text the teacher asks some questions: Could you guess what it is going to be about? How many people will speak? etc. Then learners listen to the recording for the first time using personal headphones and after that complete the online test multiple choice that the teacher has already prepared with the help of "Google Forms" [4]. The advantage of online tests is that the teacher receives immediate feedback and can at once analyze the level of understanding. Then learners listen to the audio file for the second time for more details and then answer teacher's questions: Who is speaking? What's the purpose of the telephone call? Was the conversation successful? etc. Only then learners make up their own questions and type them online using iBrainstormapp.com. (questions should differ from learner to learner), answer each other's questions and finally the teacher asks learners to play out a similar situation and gives them the examples of the situations. The main focus of the task is on listening but it is impossible to develop only one skill, they are improving together. In this task writing and listening are also engaged.

Such mobile tools as blogs, notes, e-mail etc. can contribute to the formation and development of writing skills. Every mobile device gives an opportunity to type a text and if there are any doubts it is easy to correct it. In everyday life people use notes, messages, e-mail many times a day therefore it won't be difficult for them to apply their skills in the process of foreign language learning. Moreover mobile devices with the Internet provide immediate feedback from the teacher or the colleagues.

While training speaking skills we suggest students record themselves to listen to or to watch their presentation to assess the result and to look as if they were from the outside. Furthermore learners have a chance to save their recordings and then compare their speeches with others that serves to evaluate their progress.

The development of the four basic language skills is a complex process. Learners cannot improve their receptive and productive skills separately because all of them are related to each other and present a single whole.

\section{Findings and discussion}

The presented mobile tasks were implemented into the traditional language training course for adult learners within the program of Additional Vocational Education. The participants of the experimental learning were studying general English along with business English. The syllabus for the first-semester learners is intended to 200 academic hours that is equal to 55 lessons. The whole program includes 1200 academic hours. During the first 
semester learners study different topics both social and commercial. Commercial topics are as follows: "Making an appointment", "Meeting a businessman", "Discussing contract terms". 20 lessons from 55 are dedicated to commercial topics. The tasks that we offered were integrated within these 20 lessons because the main focus of the program is on business issues as they are considered to be the most difficult ones. The age of the learners was from 25 to 51 . All the mobile devices used were learners' private property. After the experimental learning all the 43 students from 3 groups were offered the questionnaire:

Q1. I know how to use my mobile device effectively for language learning.

Q2. I have started listening to English recordings on the move.

Q3. I receive immediate feedback from the teacher and my colleagues.

Q4. My level of proficiency has increased with the help of mobile activities.

Q5. I have started communicating more in English (orally and in writing).

The obtained results show learners' interest to mobile activities (see Figure 1).

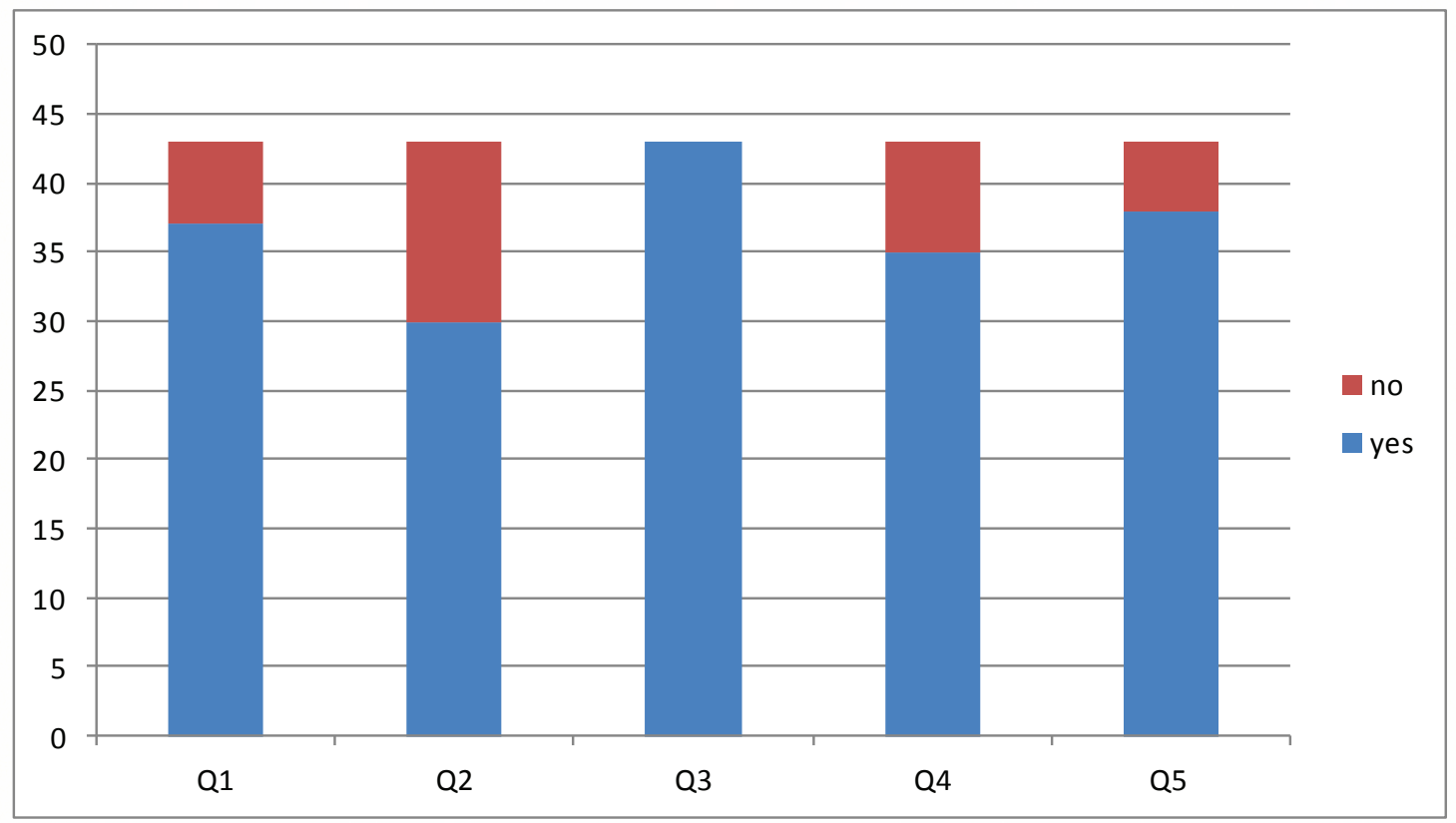

Figure 1 The results of the questionnaire

Before the integration of the mobile tasks into the English learning process all learners knew well how to use any mobile device to communicate with the help of mobile apps and messengers. However, not all of them were aware of the use of mobile devices for learning, only some learners confided that they sometimes used online translators only. After the experimental learning the learners found out some new websites and apps and most of them (37 learners from 43) learned to use them properly for developing the level of their language proficiency. One more point is that listening became accessible, learners started to listen not only to their favorite music but to English recordings as well. 30 learners from 43 listen to the educational recordings even on the move and at any place they can. Moreover now the teacher's and colleagues' feedback became "legal" and real, and immediate (sometimes the speed of the response depends on the good Internet connection), before the learners hesitated whether to contact the teacher or not, they only used their groupmate chat. $100 \%$ of the learners now use this opportunity easily. In general all learners felt changes in their learning, they started communicating more (38 from 43), therefore practicing more that led to tangible progress. Their feelings are confirmed by the results of their writing and oral work and tests. 
Having analyzed the answers of the learners we can conclude that experimental learning succeeded. The results of the questionnaire show their enthusiasm and readiness to continue mobile learning that can be an effective additional resource of English language training.

\section{Conclusions}

This article focuses on different mobile tasks that can be successfully adapted in the foreign language learning process in full-time and distance learning. Mobile devices and mobile Internet present potential for the increase of exchange of information between people. Mobile educational technologies and technologies in education contribute to:

- learners' individual learning activity;

- expansion of communication in the target language;

- development of communicative and mobile competences;

- improvement of the level of language proficiency;

- learning effectiveness.

To sum up, today's learners are interested in their personal progress and in modern techniques that will help then to obtain effective results in this case we regard mobile learning as a required technique that is the most advanced and that has already shown encouraging results.

\section{REFERENCES}

1. Avramenko A. P. Means of mobile technologies appliance in foreign language teaching: development stages and modern trends. Nauchnye vedomosti Belgorodskogo gosudarstvennogo universiteta - Belgorod State University Scientific Bulletin, 2013, no. 6 (149), pp. 36-42 (in Russian).

2. Buzan T. Use Your Head. London: BBC Books? 1974. - 157 p.

3. Crompton H., Traxler J. Mobile learning and STEM: case studies in practice. Routledge, 2015. pp. 302.

4. Google Forms. Available at: https://www.google.ru/intl/ru/forms/about/ (accessed 15 January 2019)

5. Korovina S., Pushkina A., Gurova N. Online Blogs in the Process of Development of Students' Reading Skills // ERD 2016. The European Proceedings of Social \& Behavioural Sciences EpSBS. Volume XVIII, Pages 1- 672 (22 December 2016). Published by the Future Academy. 2016. pp. 298-305.

6. Kukulska-Hulme A., Traxler J. Mobile learning: A handbook for educators and trainers. Psychology press, 2005, pp. 208.

7. McQuiggan S., McQuiggan J., Sabourin J., Kosturko L. Mobile learning: A handbook for developers, educators and learners. John Wiley \& Sons, 2015. pp.384.

8. Metcalf D. S. Mobile learning and performance in the palm of your hand, HRD Press, 2006. pp. 157.

9. Nielson K. B. Mobile-assisted language learning: research-based best practices for maximizing learner success // Handbook of research on mobile learning in contemporary classrooms. IGI Global, 2016. pp. 69-93.

10. Read T., Kukulska-Hulme A. The Role of a Mobile App for Listening Comprehension Training in Distance Learning to Sustain Student Motivation. Journal of Universal Computer Science, 2015, no. 21(10), pp. 1327-1338.

11. Titova S. V. , Samoylenko O. An enquiry-based approach to develop language skills in mobile-supported classrooms. Journal of Language and Education, 2017, no. 3(3), pp. 39-49.

12. Traxler J. Current state of mobile learning // Mobile learning: transforming the delivery of education and training / edited by Mohamed Ally, Athabasca University Press, 2009. pp. 9-24.

13. Umirov A. Using of Mobile Technologies in a Foreign Language Learning: Traditions' development and Search of New Methodical Technologies // Conference proceedings. ICT for language learning. 10th Edition, 2017. pp. 107-110.

14. Wilden S. Mobile learning, Oxford University Press, 2017. pp.104.

15. Yepez-Reyes V. Mobile learning: challenging the current educational model of communication studies // Proceeding of the international conference on Information technology and Systems (ICITS 2018), 2018. pp. 1014-1021.

16. Zurita G. and Nussbaum M. A constructivist mobile learning environment supported by a wireless handheld network. Journal of computer assisted learning, 2004, no. 20, pp. 235-243.

\author{
Информация об авторе \\ Рябкова Валерия Валерьевна \\ (Российская Федерация, Москва) \\ Аспирант \\ Российский университет дружбы народов \\ E-mail: valeriyavalerievna@bk.ru
}

\author{
Information about the author \\ Valeria V. Ryabkova \\ (Russian Federation, Moscow) \\ Graduate student \\ RUDN University \\ E-mail: valeriyavalerievna@bk.ru
}

